\title{
Oral status of older people in medium to long-stay health and social care setting: a systematic review
}

\author{
Juan Antonio Ruiz-Roca ${ }^{1}$, Dora Martín Fuentes ${ }^{2}$, Francisco J. Gómez García ${ }^{3}$ and Yolanda Martínez-Beneyto ${ }^{4^{*}}$ (D)
}

\begin{abstract}
Background: Older patients who spend long periods hospitalized or those who are in a situation of institutionalization represent a risk group in this regard, as many of them suffer a degree of dependence and need help to perform the basic tasks of personal care. It is therefore important to learn more of the oral health status of this group of patients in order to make a proper assessment of the situation and to develop protocols for its management. The purpose of the study was to conduct a systematic review to ascertain the oral health status of older people patients admitted to institutions or hospitalized for a long period of time.

Methods: a systematic review of the literature published in two different databases (PubMed, Embase and Cochrane Library) was carried out, with 12 different combinations of keywords based on the following selection criteria: studies published in the last 5 years, in English and/or Spanish and/or Portuguese, with samples of $\geq 30$ patients, performed in patients older than 65 years, admitted to any type of institution and/or hospital center for at least 7 days and in which the state of hard and/or soft tissues of the oral cavity were evaluated in some way. The selected articles were subjected to a thorough analysis.

Results: The search strategy covered 1.014 articles: 689 from Pubmed and 325 from Cochrane Library. After applying the eligibility criteria, five articles were selected for our review. The level of evidence of the articles was, a sample of 773 patients most of them were women with an average age older than 70 years old.

Conclusions: The oral health of patients aged more than 65 is worse than that of the rest population. Long hospital stays or being institutionalized in a residence makes this group susceptible to a worsening of their oral health status. It is necessary to develop protocols for the oral health care of these patients, accompanied by training programs for the personnel responsible.
\end{abstract}

Keywords: "Older inpatients", "older hospitalized patients", "long term hospitalization", "long term inpatients", "Oral health", "Oral status"

\footnotetext{
* Correspondence: yolandam@um.es

${ }^{4}$ Department of Preventive and Community Dentistry, Faculty of Medicine-Dentistry, University of Murcia, Murcia, Spain

Full list of author information is available at the end of the article
}

(c) The Author(s). 2021 Open Access This article is licensed under a Creative Commons Attribution 4.0 International License, which permits use, sharing, adaptation, distribution and reproduction in any medium or format, as long as you give appropriate credit to the original author(s) and the source, provide a link to the Creative Commons licence, and indicate if changes were made. The images or other third party material in this article are included in the article's Creative Commons licence, unless indicated otherwise in a credit line to the material. If material is not included in the article's Creative Commons licence and your intended use is not permitted by statutory regulation or exceeds the permitted use, you will need to obtain permission directly from the copyright holder. To view a copy of this licence, visit http://creativecommons.org/licenses/by/4.0/ The Creative Commons Public Domain Dedication waiver (http://creativecommons.org/publicdomain/zero/1.0/) applies to the data made available in this article, unless otherwise stated in a credit line to the data. 


\section{Background}

In light of the increase in life expectancy, aging is "on the verge of becoming one of the most significant social transformations of the twenty-first century" [1]. In Spain, people over 65 represent $19.2 \%$ of the total population [2], a figure that will reach $25.2 \%$ in 2033 [3].

This makes it necessary to reconsider the way in which we attend and treat older patients in society [4], not just those who have sufficient personal autonomy but also those, estimated to represent around 3\% of the elderly $[5,6]$, who live in institutions and need some kind of specific care. Despite this need, there are insufficient studies that describe the situation in which this population group find themselves and which might contribute to improving the attention given to them and therefore increase their quality of life. For example, in Spain there are no studies published in which the physical, medical and psychological conditions of the institutionalized older population are evaluated [5].

The progress and improvements that have been made in dentistry, as well as new patterns of care and prevention, have meant that it is increasingly possible to reach older people with a large number of teeth and in a better state of dentition than ever before [7, 8] although there is still a tendency for the older to be vulnerable to caries and periodontitis [8]. Oral pathologies can significantly affect health and general welfare of the population, and lead to alterations in speech, the poor pronunciation of certain words, or deficient food intake, raising the risk of malnutrition [9] due to problems with chewing or swallowing. Moreover, oral health can have a negative effect on facial aesthetics, lowering self-esteem and harming the psychosocial well-being of the individual [10-12]. Numerous studies have described the relationship between poor oral health and the emergence of systemic diseases, ranging from heart disease or Diabetes Mellitus to respiratory diseases, such as pneumonia $[8,10,13,14]$.

Diseases such as Parkinson's or Alzheimer's, or neuromuscular disorders, are some of the reasons that many are no longer able to carry out oral care tasks, due to a loss of manual dexterity, basically because of a loss of motor and cognitive skill, or because they do not remember how to brush their teeth or are not able to follow the instructions on how to do so themselves [11].

In the case of geriatric patients, the frequent coexistence of several diseases and disorders in the same patient must also be taken into account. Comorbidity in this population makes them especially susceptible to oral pathologies, often as a result of the medication they are taking, which increase the risk of tooth decay through hyposalivation [10]. In addition, some disorders may give rise to physical, cognitive or even motivational limitations that interfere with the development and habit of practicing good oral hygiene $[11,15,16]$.

Added to the vulnerability of geriatric patients in this respect, other factors may limit their access to oral attention, such as an inability to assume the costs of treatments reduced physical mobility, the lack of transport or the absence of caregivers or family members who can accompany them. In addition, the work they used to do, their social environment or their own idiosyncrasies may mean the person lacks the ability to recognize the need for an a dental examination or treatment [10].

Despite the high prevalence of oral health problems in this group of patients, little or no importance is given to this problem [10], leading the World Health Organization (WHO) to advise on the need to increase awareness, on a social, cultural and medical level, of oral health as a major component of overall health and quality of life. The organization strongly recommends that countries develop programmes to meet the needs of their older citizens in this respect and to research the problem of oral care in the older people, due to an increase in the overall incidence of non-transmissible diseases [17]. A survey of the oral health of older patients carried out by the WHO revealed that oral health programmes targeting this population group are very rare [17], and that dental intervention tends to be therapeutic rather than (ideally) preventive. That is why hospitalization or long stays in care centers present a good opportunity for providing dental assistance that would otherwise not be offered to the general older population [10].

The removal of bacterial plaque at least twice a day (morning and evening) is essential for maintaining oral health, especially in dependent older people. However, despite the important role that staff in hospitals and other long stay centers such as nursing homes, could play in maintaining and influencing oral health, they do not know what care and oral hygiene protocols should be followed with the older people, except those patients who are at risk of pneumonia associated with mechanical ventilation [11].

Although oral pathologies are among the most common chronic diseases and represent an important public health problem due to their prevalence and the expense of treatment [15], there is a general but erroneous belief that oral hygiene and care are unimportant [11]. When patients, for different reasons, reject oral care, staff simply accept their refusal. However, refusing treatment would not be tolerated in other interventions - for example, measuring the level of glucose in the blood or the blood pressure of a patient. This situation is doubly severe in older patients with dementia who are reluctant to be cared for by third parties, Moreover, care providers may not be in a position to offer proper care, either 
because the patient refuses or because they are overworked and decide not to assist them. For all of the above, these patients can be considered extremely vulnerable and are at higher risk than the general older population [11].

Bilder et al. [15] describes how poor oral health and limited access to oral care for adults in long-term care centers, as well as the lack of detailed guidelines, are a reflection of insufficient scientific evidence concerning the dental care support techniques that can be offered [11]. This clearly does not help when attempts are made to reverse this situation. However, problems of oral health, ranging from dental caries to chewing problems or pain, constitute the most frequent treatment needs and are among the least successfully resolved health problems in the population group consisting of older people and the disabled [15].

For all these reasons, we think that the lack of information, documentation and prevention concerning the oral health of older patients can have an advese impact on health, i.e., on the state of complete physical, mental and social well-being.

Our main objetive, then, was to conduct a systematic review to ascertain the state of oral health of older patients in an institution for a long period of time, analysing those parameters that could reveal their current oral situation. Secondary objectives were: to see whether any deterioration of oral health detected in these patients is affected by their being in a hospital or residence; to ascertain whether a standard protocol exists concerning the oral health care of these patients; to compare the information obtained with published scientific literature, and, if no relevant information exists, to propose a line of research to establish a prevention-based protocol for oral care in the older population, especially those in long stay facilities.

The literature search strategy followed in making this systematic review was in accordance with the PICOS framework [18]. The focus question was: What is the state of oral health of institutionalized older patients?.

\section{Methods}

\section{Study design}

A systematic review of the literature was managed by two reviewers (JARR and DMF) independently and conducted an exhaustive search of each database.

Following PRISMA (Preferred Reporting Items for Systematic Reviews and Meta-analyzes Statement Checklist) 2009 statements (http: www.prismastatement.org) throughout the selection process and the last manual updated by the Cochrane Collaboration, for the preparation of systematic reviews of the literature of the year 2009" [19]. Institutional review board approval was not required for this review.
In the first round only titles and abstracts of retrieved articles were analyzed. Then in a second round all considered eligible studies were fully examined and final decisions about inclusions were made. In case of disagreement a third reviewer (YMB) participated in order to reach consensus. Cohen's kappa coefficient was used to evaluate the disagreement between the researchers.

Following the methodology of evidence-based medicine, the PICO strategy was used, in order to prepare the research question to which we will try to answer in this work; Population (P): older patients, aged 65 and over admitted to hospital or geriatric center for periods of more 7 days; Intervention (I): To analyze the following parameters: Oral health indexes such as DMFT (Decayed, Missing, Filled Index) and treatment needs index and oral hygiene protocols Comparison (C): Oral health status among patients who are institutionalized versus non- older subjects; Outcome $(\mathrm{O})$ : Poorer results in patients institutionalized in the periodontal index score.

\section{Search strategy and databases}

An intensive search was performed in three of the main scientific databases such as the Cochrane Library, Medline via Pubmed and Embase. Only articles published in English, Spanish or Portuguese within the 5 year period 1 January 2014 to 1 January 2019 were consulted. The search strategy used terms from the controlled vocabulary MeSH (Medical Subject Headings) and the Boolean operators "AND", "OR" and "NOT", as well as terms related to the study population (elderly inpatients, elderly hospitalized patients, long term hospitalization, long term inpatients, oral health oral status and oral pathology).

\section{Selection criteria}

The following inclusion and exclusion criteria were followed in this systematic review (Table 1). The sample was $\geq 50$ individuals, because that amount of sample is statistically representative, usually. In Spain, an older patient is considered to be $\geq 65$ years old.

\section{Assessment of Bias in studies}

From each of the articles, information was extracted, such as sample size, study design, any intervention and the measures of the results, how the results were measured/analysed/presented?. Articles are classified by reference to their level of scientific evidence according to the criteria described by the Scottish Intercollegiate Guidelines Network (SIGN), which provides checklists to assess the quality of: systematic reviews \& metaanalyses, randomized clinical trials, cohort studies, casecontrol studies, diagnostic studies, and economic studies. Each checklist is accompanied by notes to aid 
Table 1 Inclusion and exclusion criteria

INCLUSION CRITERIA
Studies published in the last 5 years
Case-control, cross-sectional, longitudinal and cohort studies
Humans
Older patients $\geq 65$ years old
Sample $\geq 50$ individuals
Entered in some type of institution or hospital center for a period $\geq 7$
days
In which the situation of hard and/or soft tissues the oral cavity was
evaluated in some way

\section{EXCLUSION CRITERIA}

Not published un english, spanish or portuguese language

Systematic Review, Meta-Analysis, Case Report, Letter, Editorial, Congress

Children, teenagers and/or non-older adults

Studies in which the essential data are missing in order to obtain a profile of homogeneous works

Studies whose access to the complete text was under private subscription completion, and written responses to the individual questions are used, with users then assigning studies an overall rating according to specified criteria. The full set of checklists and detailed notes on their use are available from SIGN [19].

\section{Results}

The search culminated in five studies that fulfilled both the inclusion and exclusion criteria and which were conducted from 1 January 2014 to 1 January 2019 (Fig. 1).

\section{Quality assessment}

According to these criteria, the articles selected for our systematic review had the following levels of evidence and degrees of recommendation and the Risk of bias for non-randomized studies assessed with ROBINS-I Cochrane tool. (Tables 2 and 3).

\section{Basic results}

Of the five studies selected for this systematic review (Fig. 1), two were carried out in Europe [9, 20], two in Asia [21, 22], and one in Australia [23].

All the works were based on with a sample size that could offer extrapolated data ( $\geq 50$ older patients): Poisson et al. [9] 159 patients, Gerritsen et al. [20] 355, Chen et al. [21] 120, and that smallest, Murray et al. [23] and Nakayama et al. [22] with 89 and 50 patients, respectively, making a total of 773 patients.

Although only two studies [20, 21] specified the age range of the patients, the average age of all participants in the studies was over 70 years.

In three studies $[9,20,21]$ the proportion of women in the sample was higher than that of men. As regards the total number of participants in the papers included in the review, the proportion of women who participated in



Fig. 1 Flow diagram of the search processes and results 
Table 2 Risk of bias for non-randomized studies assessed with ROBINS-I Cochrane tool

\begin{tabular}{|c|c|c|c|c|c|c|}
\hline Risk of Bias domains included in ROBINS-I Cochrane tool. & $\begin{array}{l}\text { Category of } \\
\text { BIAS }\end{array}$ & $\begin{array}{l}\text { Poisson } \\
\text { et al. }\end{array}$ & $\begin{array}{l}\text { Gerritsen } \\
\text { et al. }\end{array}$ & $\begin{array}{l}\text { Chen } \\
\text { et al. }\end{array}$ & $\begin{array}{l}\text { Nakayama } \\
\text { et al. }\end{array}$ & $\begin{array}{l}\text { Murray } \\
\text { et al. }\end{array}$ \\
\hline \multicolumn{7}{|l|}{ Pre-intervention domains } \\
\hline 1.Bias due to confounding. & Confounding & 3 & 2 & 1 & 2 & 3 \\
\hline 2. Bias in selection of participants into the study. & $\begin{array}{l}\text { Selection } \\
\text { Bias }\end{array}$ & 3 & 1 & 1 & 2 & 2 \\
\hline \multicolumn{7}{|l|}{ At-intervention domain } \\
\hline 3. Bias in classification of interventions. & $\begin{array}{l}\text { Information } \\
\text { bias }\end{array}$ & 1 & 1 & 1 & 1 & 2 \\
\hline \multicolumn{7}{|l|}{ Post-intervention domains } \\
\hline $\begin{array}{l}\text { 4. Risk of bias due to deviations from the intended interventions (effect } \\
\text { of assignment to intervention) }\end{array}$ & Confounding & 2 & 2 & 1 & 1 & 1 \\
\hline 5. Bias due to missing data & $\begin{array}{l}\text { Selection } \\
\text { Bias }\end{array}$ & 2 & 2 & 1 & 1 & 1 \\
\hline 6. Bias in measurement of the outcome & $\begin{array}{l}\text { Information } \\
\text { bias }\end{array}$ & 1 & 1 & 1 & 1 & 1 \\
\hline 7. Bias in selection of the reported result & $\begin{array}{l}\text { Reporting } \\
\text { bias }\end{array}$ & 2 & 1 & 1 & 1 & 1 \\
\hline Overall Risk of BIAS for the results & & 3 & 2 & 1 & 2 & 3 \\
\hline
\end{tabular}

the studies was higher (1:1.6 male to female ratio), which can be explained by the greater life expectancy of women.

Gerritsen and co-workers [20] took as their sample a group of older subjects from three retirement homes, while Chen et al. [21] studied subjects from a geriatric medical center and Murray et al. [23] patients from three rehabilitation centers for patients who had suffered a cerebrovascular accident (CVA). Poisson et al. and Nakayama et al. $[9,22]$ developed their studies in hospitals, and Poisson et al [9] worked in the geriatrics area of a hospital. Nakayama et al. [22] focused on patients suffering ALS (Amyotrophic Lateral Sclerosis) with nasogastric and artificial respiration. None of the selected studies specified whether they were in public or private centers.

\section{Causes of admission of patients}

Except for Murray et al. [23] and Nakayama et al. [22], who worked with very specific types of patient (patients in rehabilitation after CVA and patients with ALS, respectively), none of the studies specified the reason for

Table 3 Quality assessment and general characteristics of included studies

\begin{tabular}{|c|c|c|c|c|c|c|c|c|c|c|}
\hline AUTHOR & $\begin{array}{l}\text { STUDY } \\
\text { DESIGN }\end{array}$ & $\begin{array}{l}\text { LEVE } \\
\text { L OF } \\
\text { EVID } \\
\text { EN } \\
\text { CE }\end{array}$ & $\begin{array}{l}\text { DEGREES OF } \\
\text { RECOMMENDATION }\end{array}$ & $\begin{array}{l}\text { SAMP } \\
\text { LE }\end{array}$ & $\begin{array}{l}\text { MEAN } \\
\text { AGE }\end{array}$ & $\begin{array}{l}\text { GEND } \\
\text { ER }\end{array}$ & $\begin{array}{l}\text { TYPE OF } \\
\text { CENTER }\end{array}$ & $\begin{array}{l}\text { REASON FOR } \\
\text { ADMISSION }\end{array}$ & $\begin{array}{l}\text { DURATION } \\
\text { OF } \\
\text { INCOME }\end{array}$ & $\begin{array}{l}\text { SYSTEMIC } \\
\text { PATHOLOGY }\end{array}$ \\
\hline $\begin{array}{l}\text { Poisson } \\
\text { et al. [9] }\end{array}$ & $\begin{array}{l}\text { Cross } \\
\text { sectional }\end{array}$ & 3 & $D$ & 159 & 85.28 & $\begin{array}{l}51 \mathrm{M} \\
189 \mathrm{~F} \\
(1: 2)\end{array}$ & Hospital & - & 17.2 days & $\begin{array}{l}74.2 \% \text { cognitive } \\
\text { disease }\end{array}$ \\
\hline $\begin{array}{l}\text { Gerritsen } \\
\text { et al. [20] }\end{array}$ & Cohort & 3 & $D$ & 355 & $\begin{array}{l}84.1 \pm \\
6.9\end{array}$ & $\begin{array}{l}110 \mathrm{M} \\
245 \mathrm{~F} \\
(1: 2.3)\end{array}$ & $\begin{array}{l}3 \text { Nursing } \\
\text { homes }\end{array}$ & $\begin{array}{l}\text { Somatic }(47 \%), \\
\text { psychogeriatric } \\
(53 \%)\end{array}$ & $\begin{array}{l}2.3 \pm 2.6 \\
\text { years }\end{array}$ & Unspecified \\
\hline $\begin{array}{l}\text { Murray } \\
\text { et al. [21] }\end{array}$ & Cohort & 3 & $\mathrm{D}$ & 89 & 74 & $\begin{array}{l}57 \mathrm{M} \\
32 \mathrm{~F} \\
(1.7: 1)\end{array}$ & $\begin{array}{l}3 \\
\text { Rehabilitation } \\
\text { homes }\end{array}$ & $\begin{array}{l}\text { CVA } \\
\text { (cerebrovascular } \\
\text { accident) }\end{array}$ & $\geq 7$ days & $\begin{array}{l}\text { Co-morbilities of CVA } \\
\text { (aphasia, apraxia, ...) }\end{array}$ \\
\hline $\begin{array}{l}\text { Makayama } \\
\text { et al. [22] }\end{array}$ & $\begin{array}{l}\text { Cross } \\
\text { sectional }\end{array}$ & 3 & $D$ & 50 & 70.7 & $\begin{array}{l}31 \mathrm{M} \\
19 \mathrm{~F} \\
(1.6: 1)\end{array}$ & Hospital & ALE & $\geq 7$ days & ALE \\
\hline $\begin{array}{l}\text { Chen et al. } \\
{[23]}\end{array}$ & $\begin{array}{l}\text { Case } \\
\text { control }\end{array}$ & 3 & $D$ & 120 & 80.28 & $\begin{array}{l}52 \mathrm{M} \\
68 \mathrm{~F} \\
(1: 1.3)\end{array}$ & $\begin{array}{l}\text { Geriatric } \\
\text { medical } \\
\text { center }\end{array}$ & $\begin{array}{l}\text { Pneumonia, } \\
\text { sepsis, urinary } \\
\text { tract infection, } \\
\text { idiopathic fever }\end{array}$ & 7-10 days & $\begin{array}{l}\text { Diabetes }(58.3 \%) \text {, } \\
\text { arterial hypertension } \\
\text { ( } 77.5 \%) \text {, dependence } \\
\text { (45\% total; 35\% } \\
\text { serious; } 20 \% \text { light) }\end{array}$ \\
\hline
\end{tabular}


admission to the centres, although Gerritsen et al. [20] and Chen et al. [21] gave a general outline. In particular, Gerritsen et al. [20] specified that $47 \%$ were in the residence for somatic reasons and $53 \%$ for psychogeriatric reasons, while Chen et al. [21] pointed out that the main diagnoses of their sample at admission were pneumonia, sepsis, idiopathic fever and infection of the urinary tract.

Two of the studies $[22,23]$ did not specify the length of the stay in the institution, but, from the information provided in the articles, we understand that all the studied patients had been in institution for at least 7 days $[21,23]$, while the longest times were those mentioned by Gerritsen et al. [20] (more than 2 years). Therefore, the subjects who had been the longest time in care were those mentioned in the only study carried out in retirement homes.

Three of the five studies $[9,21,23]$ specify at least part of the systemic pathology that participants were suffering. The remaining two $[20,22]$ did not mention whether the patients described in their studies suffered any other pathologies beyond those specified as the time of admission: somatic or psychogeriatric reasons in the case of Gerritsen et al. [20], and ALS in the case of Nakayama et al. [22]. In the study of Poisson et al. [9], $74.2 \%$ of the patients had some sort of cognitive problem. Murray et al. [23] mentioned only comorbidities derived from the CVA suffered by their patients (aphasia, apraxia, dependency, among others) and Chen et al. [21] describes the degree of dependence of their patients (total 45\%; severe 35\% and slight 20\%), along with the more common pathologies such as Diabetes Mellitus (58.3\% of patients) and high blood pressure (77.5\%). However, the most striking thing in all the studies was the number of patients who had some sort of cognitive problem or degree of dependence that made them vulnerable if they did not receive good oral care (Table 3).

None of the studies evaluated the medication that the participants were taking despite the fact that medication could be associated with the state of their oral health. Nakayama et al. [22], who measured the salivation index of their participants, only mentioned that none of the patients in the study were following any treatment that would have affected their salivary flow (radiotherapy or botulinum toxin treatment).

\section{Oral health and hygiene}

Regarding the oral health of the participants in the studies, we conclude that the authors used different methods of assessment, and only Poisson et al. [9] and Nakayama et al. [22] used the DMFT index (Decayed, Missing, Filled Teeth). However, the vast majority of patients in all the studies had poor oral health and, we understand that they were also in great need of treatment, although only Gerritsen et al. [20] specified so.
As regards oral care measures, only one study [9] did not mention that subjects follow any kind of oral hygiene protocol. Gerritsen et al. [20] mentioned that patients in the caring homes had access to $16 \mathrm{~h}$ of dental care a week and $8 \mathrm{~h}$ of oral hygiene. This is probably why new patients had greater need of treatment than long-standing residents, although this relationship was only clear in the group of edentulous patients. This fact is possible due to they had no teeth, and this made it easier to offer care and because their mental condition meant they have received special attention. Nakayama et al. [22] described the protocol followed by nurses twice a day, in which they paid attention to both the hard and soft tissues. However, it must be borne in mind that the patients who participated in the study by these authors suffered from ALS, suggesting that they followed a special protocol (even though, in our opinion, such care should be considered normal). Chen et al. [21] suggested that the oral hygiene of patients is the responsibility of the nursing staff, but did not specify any guidelines or the frequency concerning the same. However, the authors do mention the improvements shown following the intervention (brushing and rinsing twice a day) with regard to halitosis, plaque and the state of mucous membranes. No significant differences were observed between the three types of rinses used for the different groups (Chlorhexidine, saline solution and boiled water) during the examinations carried out on the 7 th day of the intervention, except for cases of halitosis, for which the best result was seen in the.

In the case of Murray et al. [23] it seems that patients only had their teeth brushed in the morning but that, due to the hygiene guidelines provided during the study (brushing with toothpaste after breakfast and dinner, and rinsing with water after the main meal, with the assistance of the staff when necessary), the oral situation of most of the patients with dysphagia improved; patients without dysphagia also improved, but not significantly so. In addition, the authors established a relationship between patient autonomy and their oral status. Improvement in the oral health of patients were recorded in the only two studies that provided oral hygiene guidelines during the studies and reassessed the oral situation of patients later [23]. It should be noted that only the studies of Poisson et al. and Gerritsen et al. [9, 20] were supervised by dentists (Table 4).

In general, the studies included in our systematic review $[9,20,3]$ found that the attention that should be given to the hygiene and oral care of patients is simply not given, and that staff, by implementing measures that are considered basic for maintaining good oral health, could improve the oral health of many people in this population. 
Table 4 General characteristics of included studies and statistical significance. ${ }^{*}$ significant at $p<0.05$ )

\begin{tabular}{|c|c|c|c|c|c|}
\hline AUTHOR & $\begin{array}{l}\text { MEDICATI } \\
\text { ON }\end{array}$ & ORAL HEALTH ASSESSMENT & $\begin{array}{l}\text { GUIDELINES } \\
\text { OF ORAL } \\
\text { HYGIENE (1) }\end{array}$ & GUIDELINES OF ORAL HYGIENE (2) & $p$-value \\
\hline $\begin{array}{l}\text { Poisson } \\
\text { et al. [9] }\end{array}$ & NO & $\begin{array}{l}\text { DMFT (20.2) } \\
\text { Need for treatment (89.3\%) }\end{array}$ & NO & $\mathrm{NO}$ & $\begin{array}{l}p=0.004^{*} \\
\text { (autonomy for } \\
\text { oral care vs not } \\
\text { autonomy) }\end{array}$ \\
\hline $\begin{array}{l}\text { Gerritsen } \\
\text { et al. [20] }\end{array}$ & NO & Need for treatment (70\%) & $\begin{array}{l}\text { Oral hygiene } \\
8 \mathrm{~h} / \text { week }\end{array}$ & NO & $p=0.053$ \\
\hline $\begin{array}{l}\text { Murray } \\
\text { et al. [21] }\end{array}$ & NO & $\begin{array}{l}\text { OHAT (dysphagia } 4 \text { (0-10) // not } \\
\text { dysphagia } 2(0-8)\end{array}$ & $\begin{array}{l}1 \text { brushing in } \\
\text { the morning }\end{array}$ & $\begin{array}{l}\text { Brushing toothpaste (after breakfast and } \\
\text { dinner), rinses with water (after lunch) }\end{array}$ & $\begin{array}{l}\text { dysphagia } p= \\
0.024^{*} \\
\text { not dysphagia } p= \\
0.282\end{array}$ \\
\hline $\begin{array}{l}\text { Makayama } \\
\text { et al. [22] }\end{array}$ & $\begin{array}{l}\text { Decrease } \\
\text { salival flow } \\
\text { (botix, ...) }\end{array}$ & DMFT (13) & $\begin{array}{l}\text { Twice in a } \\
\text { day }\end{array}$ & NO & $p>0.05$ \\
\hline $\begin{array}{l}\text { Chen et al. } \\
\text { [23] }\end{array}$ & NO & $\begin{array}{l}\text { Own index reviewed by } 2 \text { dentist and } \\
\text { one nurse to measure halitosis, } \\
\text { bacterial plaque and mucosal status }\end{array}$ & $\begin{array}{l}\text { Assisted by } \\
\text { nurses (does } \\
\text { not specify }\end{array}$ & $\begin{array}{l}\text { 10-15 min. After lunch and after dinner with } \\
\text { toothbrush and } 3 \text { different mouthwashes: } \\
\text { clorhexidine, saline solution and boiled water }\end{array}$ & $p=0.002^{*}$ \\
\hline
\end{tabular}

\section{Discussion}

\section{Relationship between oral and general health}

There is no doubt that a good oral health status is crucial for maintaining good general health $[8,10,13]$. In the older this relationship is much clearer, since many tend to suffer from conditions that make them susceptible to poorer oral health $[10,11,15]$.

In a study carried out in 2001, Shimazaki et al. [24] showed that older edentulous subjects not using dentures were significantly $(p<0.05)$ associated with hight risk of physical disability and mortality, independent of age and other variables $(\mathrm{OR}=1.8,95 \% \mathrm{CI})$. The decline in occlusal function resulting from tooth loss causes problems with chewing, swallowing, an food selection, and the nutritional status of edentulous people deteriorates. Therefore, Shimazaki et al. [24] concluded that those older inpatients with 20 or more teeth, leads to think that the conservation of teeth as the years pass exerts a protective role in the general state of health. These same authors studied the influence of oral health on febrile states in older inpatients during long hospital stays, and found that poor dental and oral health was linked to episodes of fever in both dentate and edentulous patients. In addition, many authors have described the relationship between poor oral health and the development of pneumonia as a result of aspiration and respiratory infections in patients with assisted ventilation [16]. This suggests that, while dental conservation work can favour the maintenance of a good general state of health in old age, the same does not apply if little attention has been paid to maintaining oral health previously.

\section{Impact of hospitalization}

Hospitalization changes the routines of people, and may cause stress or anxiety because of the pain and discomfort that they may experience during an illness [25]. For this reason, being hospitalized is an added risk when it comes to good oral health [16], as it usually results in a decline in self-esteem, leading patients to neglect personal care and hygiene at that same time that they feel worried about their disease [16, 25]. This circumstance particularly affects patients with physical or cognitive limitations [12, 25-27], who are the most vulnerable in terms of developing problems or deterioration in terms of oral health, especially during a long hospital stay or a situation of institutionalization.

\section{Lack of data on longer term institutional care settings}

Studies that have attempted to look for a relation between hospitalization and oral health were developed in Intensive Care Units (ICU), and so provide insufficient evidence since the vast majority of hospitalized patients attend other departments [25]. In addition, Sousa et al. [25] and Gibney et al. [16] found that short hospital stays in units that did not involve intensive care had a negative effect on the oral health of patients, corroborating the evidence of studies conducted in these units, and underlining the importance of studying the situation in other hospital services.

During the article selection process we were faced with the problem of the paucity of studies on elderly institutionalized or long-stay hospital patients and their oral health, although many authors $[10,16,28]$ studied emergency and short-stay patients, who were found to have previous oral health as well as systemic problems. Other studies focused on dysphagia which elderly patients frequently suffer, its risk factors and relationship with malnutrition, but without analyzing the state of their oral health [29-32], despite its importance in this disorder. In our review $[9,20-22]$, we observed that the vast 
majority of participants had poor oral health. For example, Gerritsen et al. [20] established the need for treatment in $70 \%$ of the patients in their sample, even though dental care was provided by their institution, which makes the lack of studies assessing the oral health of the older in this situation or during long hospital stays even more incomprehensible.

\section{The need for standardize protocols}

As we have seen in two of the studies included in our review $[21,23]$, compliance with the protocols that involve the basic oral hygiene measures recommended for any patient these days leads to unquestionable improvements in the oral health of patients. This has also been found in other studies carried out in chronic care facilities and in areas of geriatric rehabilitation where oral hygiene measure were under the supervision of dental professionals and/or nursing staff following a standardized protocol [28].

Health care personnel recognise the importance of hygiene and oral care [33]. However, the lack of such care in long stay institutions and hospitals [34] is frequently attributed to a lack of training and time and the little cooperation of geriatric patients themselves [33]. Many studies have pointed to the difficulty posed by applying protocols of oral hygiene in institutions such as old people's homes [20] due to the little training received by care workers concerning protocols of oral hygiene, the oral needs of older patients, and the risks and negative consequences of poor oral health $[15,16]$, as well as on the availability of and access to material to carry out related tasks [11, 35]. In addition, it has been described how a theoretical training programme is not sufficient to improve the oral care of these patients. In this context, Gammack et al. [36] found that when hygienists, auxiliary staff and nurses were given oral hygiene training on a theoretical basis using audiovisual aids and dummies rather than "real" patients, the oral health of dependent patients did not improve, perhaps because, among other reasons, staff had not received adequate training or information on the correct way to deal with the reactions of patients opposed to receiving much care [28]. However, some studies suggest that the attitude of the staff themselves towards providing oral care makes the difference between a patient accepting, asking for or neglecting oral care [11]. It is clear that oral health is not a priority in situations of lengthy hospitalization or institutionalization $[11,37]$. As we have seen in the results of the review, only one study [22] presented a detailed oral hygiene protocol to be applied twice a day, although, being a protocol used in patients with ALS, we understand that this is a special feature because of the medical condition in question.

\section{The situation in Spain}

In Spain, according to National Oral Health Surveys, carried out in 2015 , the $20 \%$ of the population over 65 years old, worry less about their oral health, and visit the dentist less frequently [38]. Perhaps, for this reason, in the group of 65-74 years, the SIC (Significant Caries Index) of Bratthall, represents the highest value, a $25.27 \pm 2.80$, compared to the adult population (34-44 years) or adolescent population of 15 years old, whose values are $14.29 \pm 3.86$ and $3.73 \pm 2.11$, respectively [39].

Despite this situation, and the greater risk of developing oral pathologies as mentioned above, the number of complications and problems that can occur in this population group due to deficient oral health, there are no specific programmes dedicated to the prevention or promotion of oral health in the older population in Spain. In the published scientific literature, we only found one study dedicated to the development of a geriatric dental care programme (PADGE, in its Spanish acronym) [40] developed in the Public University of Navarra (Spain).

However, as in many cases the proposed programme remained just a proposal, and to this day remains to be implemented even at a regional level, and this in a $\mathrm{Au}-$ tonomous Community regarded as being a leader in preventive oral health programs. It seems that neither governmental nor local authorities consider worthwhile the logistic and economic effort that such a programme would involve. Population aging and the poor dental state of many people over 65 years of age, accompanied by a lack of specific studies and the quality of those that exist (the studies included in our systematic review had a level of evidence of 3 and grade of recommendation D, according to the SIGN criteria) on long term stays in hospitals and other institutions, together with the lack of protocols for promoting good oral hygiene and health care in nursing homes and hospitals, underline the importance of this line of study in the future. For this reason, and due to the lack of time available to develop the present overview, we intend to expand the study by developing a universal protocol for dental care in institutionalized patients.

\section{Conclusions}

The oral health of older patients aged over 65 years, whether hospitalized for long periods of time or living in institutions, is deficient, and a homogeneity in methodology of studies are needed. Furthermore, theoretical and practical continuous training courses would be necessary with the aim of training caregivers in oral health techniques.

\section{Abbreviations}

WHO: World Health Organization; DMFT: Decayed, Missing, filled teeth; JARR: Juan Antonio Ruiz Roca; DMT: Dora Martin Fuentes; YMB: Yolanda Martínez Beneyto; FJGG: Francisco Jose Gomez Garcia; SIGN: Scottish 
Intercollegiate Guidelines Network; RCT'S: Ramdomized Controlled Trials; CVA: Cerebral vascular accident; ALS: Amyotrophic Lateral Sclerosis; ICU: Intensive Care Unit; SIC: Significant Caries Index; PADGE: Geriatric Dental Care Programme; OR: Odds Ratio; Cl: Confidence Interval; DMFT: Decayed, Missing, Filled Index

\section{Acknowledgements}

"not applicable".

\section{Authors' contributions}

J.A.R.R. and D.M.F. conducted the systematic literature search and carried out study selection. In cases of disagreement, the two authors consulted Y.M.B., who helped them reach a consensus. J.A.R.R. and F.J.G.G. extracted data from the articles included in the review and assessed the quality of the studies. J.A.R.R., Y.M.B. and F.J.G.G wrote the main text. J.A.R.R., and D.M.F. prepared the figures and tables. All authors have reviewed the manuscript.

\section{Funding}

This research did not receive any specific grant from funding agencies in the public, commercial, or not-for-profit sectors.

\section{Availability of data and materials}

Data and materials are available ordering to the corresponding author.

\section{Declarations}

Ethics approval and consent to participate

"not applicable, there is not data from patients".

\section{Consent for publication}

Not applicable.

\section{Competing interests}

We declare that we have no proprietary, financial, professional or other personal interest of any nature or kind, in any product, service and/or company that could be construed as influencing the position presented in the manuscript entitled "Oral Status of older people in medium to long-stay health and social care setting: a systematic review",

\section{Author details}

${ }^{1}$ Department of Gerodontology, Faculty of Medicine-Dentistry, University of Murcia, Avda Marqués de los Velez s/n. Clínica Odontológica Universitaria, Murcia 30008, Spain. ${ }^{2}$ Department of Gerodontology, Research Investigations External, Faculty of Medicine-Dentistry, University of Murcia, Murcia, Spain. ${ }^{3}$ Department of Oral Medecine, Faculty of Medicine-Dentistry, University of Murcia, Murcia, Spain. ${ }^{4}$ Department of Preventive and Community Dentistry, Faculty of Medicine-Dentistry, University of Murcia, Murcia, Spain.

Received: 24 November 2020 Accepted: 26 May 2021

Published online: 14 June 2021

\section{References}

1. UN. United Nations. Global affairs. Aging..2018 http://www.un.org/en/ sections/issues-depth/ageing/. Accessed 15 January 2019.

2. INE a: Statistics National Institute. Demography and population. Population figures and demographic censuses 2018 http://www.ine.es/prensa/cp_e201 8_p.pdf Accessed 20 March 2019.

3. INE b: Statistics National Institute. Demography and population. Population figures and demographic censuses. Population projections. Latest data.2018 https://www.ine.es/prensa/pp_2018_2068.pdf . Accessed 25 April 2019.

4. WHO. World Health Organization. World report on aging and health. 2015. https://www.who.int/ageing/publications/world-report-2015/es/. Accessed 2 February 2019.

5. Acevedo Alcaraz E, Alcaraz Baños M, Benito Martínez J, Robert Muir B, Navalon VC. Situation of our institutionalized elderly in residences and needs for their social integration. Azarbe Revista Internacional de Trabajo Social y Bienestar. 2014;3:279-82.

6. INE c: Statistics National Institute. Demography and population. Population figures and demographic censuses. Population and housing censuses. Results. Population characteristics in groups. 2018. https://www.ine.es/ prensa/np777.pdf. Accessed 24 April 2019.
7. Peltola P, Vehkalahti MM, Wuolijoki-Saaristo K. Oral health and treatment needs of the long-term hospitalised elderly. Gerodontology. 2004;21:93-9.

8. Scannapieco FA, Cantos A. Oral inflammation and infection, and chronic medical diseases: implications for the elderly. Periodontol. 2016;72:153-75.

9. Poisson P, Laffond T, Campos S, Dupuis V, Bourdel-Marchasson I. Relationships between oral health, dysphagia and undernutrition in hospitalised elderly patients. Gerodontology. 2016;33:161-8.

10. Chróinín D, Montalto A, Jahromi S, Ingham N, Beveridge A. Foltyn POral Health Status Is Associated with Common Medical Comorbidities in Older Hospital Inpatients. J Am Geriatr Soc. 2016;64(8):1696-700.

11. Coker E, Ploeg J, Kaasalainen S, Carter N. Nurses' oral hygiene care practices with hospitalised older adults in postacute settings. Int J Older People Nurs. 2017:12:1-12.

12. Ngo DYJ, Thomson WM, Subramaniam M, Abdin E, Ang KY. The oral health of long-term psychiatric inpatients in Singapore. Psychiatry Res. 2018;266: 206-11.

13. Liao YM, Tsai JR, Chou FH. The effectiveness of an oral health care program for preventing ventilator-associated pneumonia. Nurs Crit Care. 2015;20(2): 89-97.

14. Górska R, Dembowska E, Konopka TP, Wysokinska-Miszczuk J, Pietruska M, Ganowicz E. Correlation between the state of periodontal tissues and selected risk factors for periodontitis and myocardial infarction. Adv Clin Exp Med. 2017;26(3):505-14.

15. Bilder L, Yavnai N, Zini A. Oral health status among long-term hospitalized adults: a cross sectional study. Peer J. 2014;2:E423.

16. Gibney JM, Wright C, Sharma A, D'Souza M, Naganathan V. The oral health status of older patients in acute care on admission and Day 7 in two Australian hospitals. Age Ageging. 2017;46:852-6.

17. Petersen PE, Yamamoto T. Improving the oral health of older people: the approach of the WHO Global Oral Health Programme. Commun Dentistry Oral Epidemiol. 2005;33(2):81

18. Moher D, Liberati A, Tetzlaff J, Altman DG, PRISMA GROUP. Preferred reporting items for systematic reviews and meta-analyses: the PRISMA statement. Int J Surg. 2010;8(5):336-41.

19. Harbour R, Miller J. A new system for grading recommendations in evidence based quidelines. BMJ. 2001;323(7308):334-6.

20. Gerritsen P, Cune M, van der Bilt A, Abbink J, de Putter C. Effects of integrated dental care on oral treatment needs in residents of nursing homes older than 70 years. Spec Care Dentist. 2015;35:132-7.

21. Chen SC, Weng LC, Tsai SC, Wang SM, Han HM. Effectiveness of Oral Rinsing Solutions on Mucus, Odor, and Plaque in the Hospitalized Elderly in Taiwan. Clin Nurs Res. 2017;1:1054773817744151.

22. Nakayama R, Nishiyama A, Matsuda C, Nakayama Y, Hakuta C, Shimada M. Oral health status of hospitalized amyotrophic lateral sclerosis patients: a single-centre observational study. Acta Odontol Scand. 2018;76:294-8.

23. Murray J, Scholten I. An oral hygiene protocol improves oral health for patients in inpatient stroke rehabilitation. Gerodontology. 2018;35:18-24.

24. Shimazaki Y, Soh I, Saito T, Yamashita Y, Koga T, Miyazaki H, et al. Influence of dentition status on physical disability, mental impairment and mortality in institutionalized elderly people. J Dent Res. 2001;80:340-5.

25. Sousa LLA. Silva Filho WLSe, Mendes RF, Moita Neto JM, Prado Junior RR Oral health of patients under short hospitalization period: observational study. J Clin Periodontol. 2014;41:558-63.

26. Chu KY, Yang NP, Chou P, Chiu HJ, Chi LY. Comparison of oral health between inpatients with schizophrenia and disabled people or the general population. J Formos Med Assoc. 2012;111:214-9.

27. Kossioni $A E$, Kossionis GE, Polychronopoulou A. Oral health status of elderly hospitalised psychiatric patients. Gerodontology. 2012;29(4):272-83.

28. Gibney JM, Wright FA, D'Souza M, Naganathan V. Improving the oral health of older people in hospital. Australas J Ageing. 2019;38:33-8.

29. Kuroda Y. Factors associated with the level of oral intake in hospitalized older adults with dysphagia: The importance of mental activity. Clin Nutr ESPEN. 2016;13:e52-4.

30. Leder SB, Suiter DM, Agogo GO, Cooney LM Jr. An Epidemiologic Study on Ageing and Dysphagia in the Acute Care Geriatric-Hospitalized Population: A Replication and Continuation Study. Dysphagia. 2016;31(5):619-25.

31. Maeda K, Akagi J. Decreased tongue pressure is associated with sarcopenia and sarcopenic dysphagia in the elderly. Dysphagia. 2015;30(1):80-7.

32. Martín A, Ortega O, Roca M, Arús M, Clavé P. Effect of A Minimal-Massive Intervention in Hospitalized Older Patients with Oropharyngeal Dysphagia: A Proof of Concept Study. J Nutr Health Aging. 2018;22:739-47. 
33. Frenkel H, Harveys I, Needs K. Oral health care education and its effect on caregivers' knowledge and attitudes: a randomized controlled trial. Community Dent Oral Epidemiol. 2002;30:91-100.

34. Shay K. Oral neglect in the institutionalized elderly part 2: The role of the dentist and the standard of care. Spec Care Dentist. 1990;10:200-3.

35. Zimmerman S, Austin S, Cohen L, Reed D, Poole P, Ward K, et al. Readily Identifiable Risk Factors of Nursing Home Residents' Oral Hygiene:

Dementia, Hospice, and Length of Stay. J AM Geriatr Soc. 2017;65:2516-21.

36. Gammack J, Pulisetty S. Nursing education and improvement in oral care delivery in long term care. JAMDA. 2009;10:658-61.

37. Fitzpatrick J. Oral health care needs of dependent older people: Responsibilities of nurses and care staff. J Adv Nurs. 2000;32:1325-32.

38. White book. Populaton survey. Oral Health in Spain 2015. Consejo General de Colegios de Dentistas de España. Procter \& Gamble España, SA. 2016. https://www.consejodentistas.es/comunicacion/actualidad-del-consejo/ publicaciones-del-consejo/libros-del-consejo/item/1204-libro-blanco-2015. html. Accessed 2 April 2019.

39. Bravo Pérez M, Almerich Silla JM, Ausina Márquez V, Avilés Gutiérrez $P$, Blanco González JM, Canorea Díaz E, et al. Oral Health survey in Spain 2015. RCOE. 2016;21:8-48.

40. Fernández Pan A. Gerodontological dental assistance planning-PADGE [TFM en Internet]. [Navarra]: University of Navarra. 2014. http://academicae.unava rra.es/bitstream/handle/2454/14023/Adriana\%20Fernández\%20Pan. pdf?sequence=1. Accessed 19 April 2019.

\section{Publisher's Note}

Springer Nature remains neutral with regard to jurisdictional claims in published maps and institutional affiliations.

Ready to submit your research? Choose BMC and benefit from:

- fast, convenient online submission

- thorough peer review by experienced researchers in your field

- rapid publication on acceptance

- support for research data, including large and complex data types

- gold Open Access which fosters wider collaboration and increased citations

- maximum visibility for your research: over $100 \mathrm{M}$ website views per year

At $\mathrm{BMC}$, research is always in progress.

Learn more biomedcentral.com/submissions 